\author{
KULTURA \\ i \\ POLSKA AKADEMIA NAUK \\ KOMITET SOCJOLOGII \\ INSTYTUT STUDIÓW POLITYCZNYCH \\ 2016, $\mathrm{nr} 4$
}

ELŻBIETY TARKOWSKIEJ SOCJOLOGIA OTWARTA

\title{
KULTURA TERAŹNIEJSZOŚCI W UJĘCIU GLOBALNYM I LOKALNYM
}

\section{WPROWADZENIE: CZAS I KULTURA WSPÓŁCZESNA}

Kategoria czasu - jak chcą niektórzy badacze - „jedna z najbardziej kontrowersyjnych kategorii używanych tak w naukach przyrodniczych, jak i społecznych" (Castells 2007, s. 429) - stała się dziś podstawową kategorią interdyscyplinarnego dyskursu dotyczącego społeczeństwa i kultury, ich obecnej kondycji i współczesnych przeobrażeń. Różne aspekty czasu i jego zmienne formy pełnią funkcję swoistego pryzmatu, pozwalającego dojrzeć najistotniejsze cechy życia społecznego i kultury. O czasie piszą dziś wszyscy, lawinowo rośnie liczba badaczy różnych specjalności - socjologów, antropologów, znawców kultury, literatury, sztuki i innych dziedzin - którzy ważnym elementem swoich analiz i koncepcji uczynili czas rozumiany jako zjawisko społeczne i kulturowe lub, inaczej rzecz ujmując, temporalny wymiar życia społecznego i kultury. Wystarczy wspomnieć Norberta Eliasa, Niklasa Luhmanna, Pierre'a Bourdieu, Zygmunta Baumana, Anthony'ego Giddensa, Umberta Eco, Paula Virilio, Davida Harveya, Manuela Castellsa, Johna Urry'ego. Ich prace pokazują, że w społeczeństwach współczesnych czas odgrywa rolę nieznaną wcześniej w dziejach, opisuje się je jako poddane obsesji czasu (time-obsessed society) (Young, Schuller 1988), jako imperium zegara (Aveni 2001). Mówi się o chronocentryzmie (Elias 1992), despotyzmie czasu (MacIver), tyranii chwili (Erik-

PierwoĐruk w: Anna Malewska-Szałygin, Magdalena Radkowska-Walkowicz (red.), Antropolog wobec wspótczesności. Tom $w$ darze Profesor Annie Zadrożyńskiej, Instytut Etnologii i Antropologii Kulturowej UW, Warszawa 2010, s. 107-120. 
sen 2003), kulturze przyspieszenia (Bertman 1998), pisze się o współczesnym głodzie czasu (Robinson, Godbey 1999). Można by mnożyć pomysłowe metafory i wyraziste charakterystyki próbujące oddać wyjątkową rolę czasu w kulturze współczesnej i wyjątkowy status „teraz”, chwili, teraźniejszości, pozwalający mówić o kulturze teraźniejszości. Za tymi wszystkimi określeniami kryją się charakterystyczne dla współczesności zjawiska kompresji czasu i przestrzeni oraz konsekwencje tych zjawisk dla jednostek i zbiorowości; przemiany statusu teraźniejszości, przeszłości i przyszłości i wyjątkowe miejsce w kulturze współczesnej teraźniejszości; sposoby doświadczania czasu i wpływ na nie nowych technologii informacyjnych i komunikacyjnych, a także kultury konsumpcyjnej; obsesje czasu, choroby cywilizacyjne związane z pośpiechem, przyspieszeniem i nowymi napięciami w zakresie doświadczania czasu, nowe zagrożenia i propozycje przeciwdziałania im; wpływ zmieniających się doświadczeń i koncepcji czasu na życie społeczne i więzi międzyludzkie; zróżnicowania i podziały społeczne, a także konflikty związane z czasem.

Tytułowe hasło kultury teraźniejszości wskazuje na problematykę uwzględniającą różne strategie i mechanizmy detemporalizacji, czyli sprowadzania czasu do chwili, do nieustannej zmiany i natychmiastowości. Można to nazwać za Manuelem Castellsem (2007, s. 432-433) formowaniem się czasu bezczasowego (timeless time). W niniejszym tekście przyjrzę się kulturze teraźniejszości jako zjawisku o zasięgu globalnym, mającemu też lokalne wcielenia, mam na myśli specyficzną polską wersję kultury teraźniejszości. Będzie to zaledwie dotknięcie tylko niektórych aspektów rozległej i wielowymiarowej problematyki i zasygnalizowanie tylko niektórych fragmentów wielkiego, interdyscyplinarnego dyskursu. Swój udział ma w nim Anna Zadrożyńska, która badała „czas niezwykły” i „czas codzienny”, wówczas gdy nie było to tak powszechne i tak popularne, jak jest dzisiaj (Zadrożyńska 1985).

\section{FENOMEN ROZSZERZONEJ TERAŹNIEJSZOŚCI ${ }^{1}$ I JEGO UWARUNKOWANIA}

Jak pokazał Stephen Kern (1983), koniec XIX i początek XX wieku (okres 1880-1914) był szczególnie istotny dla przemiany sposobów doświadczania i konceptualizacji czasu ze względu na nagromadzenie wielu zmian społecznych i kulturowych, w tym innowacji technicznych w zakresie komunikacji międzyludzkiej, prowadzących do głębokich przeobrażeń świata stworzonego

${ }^{1}$ Tak tłumaczę termin the extended present Helgi Nowotny (1994). W książce Phila Macnaghtena i Johna Urry'ego Alternatywne przyrody. Nowe myślenie o przyrodzie i społeczeństwie (2005) został on przetłumaczony jako „przedłużona teraźniejszość”. Widoczne linearne odniesienie jest tu niepożądane. Udaje się tego uniknąć przy użyciu innego przestrzennego (czas w naszej kulturze konceptualizujemy i wyobrażamy sobie przestrzennie) określenia, czyli stosowanej tu „rozszerzonej teraźniejszości”. 
przez człowieka ${ }^{2}$. W wytworzeniu nowych ram czasoprzestrzennych istotną rolę odegrały też procesy standaryzacji czasu w skali globalnej. Przyjęcie wspólnych miar czasu (co formalnie dokonało się w 1913 roku, a w życiu społecznym związane $z$ tym procesy trwają nadal) w zasadniczy sposób przyczyniło się do powstania sieci globalnej komunikacji, w sferze zarówno informacji, jak i transportu (Adam 1995). Globalizacja czasu, w rezultacie rozwoju techniki i nowych technologii, wprowadzenia wielu nowych wynalazków i innowacji technologicznych, stała się ważnym czynnikiem umożliwiającym przestrzenną ekspansję w innych dziedzinach życia zbiorowego, czyli dalsze procesy i kolejne fale globalizacji. Ujednolicanie i standaryzacja czasu, pierwotnie ograniczone do kręgu kultury europejskiej i do sfery oddziaływania chrześcijaństwa, wraz z rozwojem nowych środków komunikacji ogarnęły znacznie większe obszary globu.

Ważnym procesem dotyczącym interesujących nas tu kwestii jest nie tylko globalizacja czasu (o której pisała Barbara Adam w książce Timewatch, 1995), rozumiana jako wspólne, jednolite narzędzie koordynacji życia zbiorowego coraz większych rzesz ludności i coraz większych części globu, ale także zmieniające się relacje między przeszłością, teraźniejszością i przyszłością. Przemiany te często są interpretowane jako niezamierzone i nieprzewidziane konsekwencje nowoczesnego stosunku do czasu, charakteryzującego się znacznym przyspieszeniem, koncentracją na przyszłości, planowaniem; prowadzą one do zjawisk przeciwstawnych, polegających na rosnącej roli teraźniejszości, pochłaniającej także przeszłość i przyszłość. Fenomen ten, określony jako rozszerzona teraźniejszość (the extended present), opisany przez Helgę Nowotny w znakomitej książce Time: The Modern and Postmodern Experience (1994), jest niewątpliwie jednym $z$ kluczowych, wielkich tematów interdyscyplinarnej refleksji nad kulturą współczesną i jej charakterystycznymi cechami, znajdującymi wyraz w strukturach czasowych. Wystarczy przywołać przykłady zjawisk temporalnych kryjących się pod takimi określeniami jak: kompresja czasoprzestrzeni, czyli można powiedzieć, ściśnięcie czasu do teraźniejszości (Harvey 1989); uwspółcześnianie czasu (contemporarisation), czyli włączanie przeszłości i przyszłości do ciągle rozrastającej się teraźniejszości (Young 1988); czy powstawanie globalnej teraźniejszości (Adam 1995). Badacze opisują procesy kształtowania się bliskości (jedności) czasowej w skali globu (the time compact global society) (Fraser 1987), formowania się „czasoprzestrzeni wiecznego teraz i wszechobecnego «tutaj”” (Bauman 1998), dominacji „teraz” i kultury teraźniejszości (the nowist culture) (Bertman 1998), a także „kultury absolutnej teraźniejszości” (Heller 1996); piszą o implozji czasu (Ritzer 2001) i o „opętaniu teraźniejszością i bliską przyszłością" (Eriksen 2003). Wyrazistym przejawem dominującej roli teraźniej-

2 Temporalne skutki wprowadzania innowacji komunikacyjnych na wielu przykładach zaczerpniętych z dziewiętnastowiecznej kultury pokazują także analizy zebrane w tomie zbiorowym Szybko i szybciej (Siwicka, Bieńczyk, Nawarecki 1996). 
szości jest specyficzny rodzaj czasu, przez badaczy opisywany jako postlinearny, złożony z krótkotrwałych, wyrwanych z ciągu momentów, będący w istocie rzeczy „sukcesją epizodów bez konsekwencji” (Bauman 1998, s. 228), nazwany później przez Zygmunta Baumana (2006) czasem punktowym, a przez innych badaczy czasem momentalnym (Macnaghten, Urry 2005), czasem sprowadzającym się do chwili, „poszatkowanym w tak drobne kawałki, że prawie nic już z niego nie zostało" (Eriksen 2003, s. 16), czasem błyskawicznym (instant time) i wreszcie czasem bezczasowym (Castells 2007).

Opisywane zjawiska są efektem oddziaływania różnego rodzaju czynników, przede wszystkim rozwoju techniki, nowych technologii komunikacyjnych i informacyjnych, zmieniających zasadniczo (choć często niezamierzenie, a nawet wbrew oczekiwaniom) środowisko temporalne człowieka, jego doświadczenie czasu i stosunek do niego. Ponadto istotny wpływ mają tutaj rynek, konsumpcja i konsumpcyjny styl życia. Sprawy te są dobrze znane i szczegółowo udokumentowane, przypomnę je jedynie w zarysie.

Nowe technologie i nowe urządzenia techniczne prowadzą, jak to pokazuje wiele analiz, do wytworzenia specyficznej kultury przyspieszenia, hiperkultury w terminologii Stephena Bertmana (1998), polegającej na tym, by robić coraz więcej w coraz krótszym czasie. Człowiekowi towarzyszy dziś poczucie nieustannej presji czasu i ciągłego jego deficytu, zarówno w pracy, jak i w czasie wolnym oraz życiu prywatnym. „Ludzie spieszą się w pracy - pisał w Rytmie życia Antoni Kępiński (1983, s. 134) — dlatego niedbale ją wykonują; spieszą się w używaniu życia, dlatego jego smaku nie odczuwają; spieszą się w odpoczynku, dlatego nie mogą wypoczaḉ”. Coraz większe szybkości, właściwe urządzeniom technicznym, są narzucane znacznie wolniej funkcjonującym organizmom ludzkim, rośnie rozbieżność między tempem środowiska technicznego a szybkością fizjologiczną człowieka, jego możliwościami i ograniczeniami w percepcji nowych bodźców. „W ostatnich kilkudziesięciu latach — pisał przed laty autor Rytmu życia — człowiek przekroczył w niewiarygodny sposób swą szybkość fizjologiczną [...]. Trudno na razie określić, jak odbija się na ustroju ludzkim życie w środowisku o znacznie wyższych od jego własnych szybkościach" (Kępiński 1983, s. 134).

Późniejsze badania nad użytkownikami komputerów pokazują, że wprowadzana przez te urządzenia częstotliwość, komputerowe przyspieszenie, zmienia nasz stosunek do otoczenia, wprowadza niecierpliwość i nowe wymagania czasowe. Jeremy Rifkin w napisanej przed dwudziestu laty książce Time Wars: The Primary Conflict in Human History (1987) przypuszczał, że skutki czasowości komputerowej, a zwłaszcza konflikt między czasem biologicznym a czasem społecznym, coraz bardziej dostosowującym się do czasu komputerowego, w najbliższej przyszłości może stać się jednym z centralnych problemów (obszarem „wojny”). Nowe media, nowe środki informacji i komunikacji prowadzą do technostresu, jak to określa Bertman, powodują napięcia i stresy związane $z$ tempem i szybkością, a także $z$ nadmiarem informacji. Pozytywnie war- 
tościując zmianę, nowość, nieciągłość, fragmentaryzację, jako zwykłe, oczywiste wymiary rzeczywistości, telefon, telewizja, komputer, internet przyczyniają się do dominacji teraźniejszości, chwili bieżącej, przyzwyczajają do nieciągłości i nietrwałości. Nowe technologie, często wprowadzane w celu ułatwienia życia i oszczędzenia czasu, podnosząc standardy wykonywanych czynności lub tworząc nowe potrzeby, stają się źródłem nowych, równie lub nawet bardziej czasochłonnych zajęć, nowych stresów i napięć.

Skutki tych procesów są dalekosiężne i odbijają się na wszystkich sferach życia, znajdują wyraz $\mathrm{w}$ wartościach, obyczajach, związkach i relacjach między ludźmi, naznaczają je natychmiastowością i chwilowością. Przekształcają ideologię inwestowania w przyszłość (tak charakterystyczną dla społeczeństwa nowoczesnego nastawionego na rozwój i postęp) w praktykę krótkoterminowych gratyfikacji. Zmieniają rodzinę - jej spójność naruszona zostaje przez kult szybkości i zmiany, który tworzy wiele sił odśrodkowych o działaniu dezintegrującym. Zmieniają tożsamość, prowadzą do rezygnacji z czasochłonnych zajęć i obowiązków, zniechęcają do takich cnót jak cierpliwość, stopniowe kształtowanie charakteru czy powolne budowanie więzi międzyludzkich. Zmieniają społeczeństwo i jego system wartości. Jak powiada cytowany tu wcześniej Bertman, bliskość między ludźmi jest czasochłonna, nie ma na nią miejsca w kulturze przyspieszenia.

Drugi zespół czynników współcześnie kształtujących oblicze czasu społecznego, w tym fenomen rozszerzonej teraźniejszości, to rynek, reklama, kultura konsumpcyjna. W konsumpcyjnej hierarchii wartości na plan pierwszy wysuwa się szybkość, zmiana, przyspieszenie. Konsumpcja wymusza przewartościowanie trwania i przemijania, o czym wielokrotnie pisał Zygmunt Bauman. Trwałość, która przez większą część dziejów ludzkości była wartością, pod wpływem konsumpcji została wyparta na rzecz przemijania. Podobnie odkładanie na później, gromadzenie, oszczędzanie, które organizowało działania ludzi przez wieki i było podstawą „ducha kapitalizmu”, dziś zdezaktualizowało się jako sprzeczne z wymogiem szybkiego zużywania i pozbywania się zużytych przedmiotów, by nabyć nowe, oraz z modelem życia na kredyt, zadłużania się.

Bezpośrednim efektem ekspansji kultury konsumpcyjnej jest zmiana istoty czasu. Czas konsumpcji to czas teraźniejszości, chwili, nieustannej zmiany „Spektakularna kariera «teraz», wywołana rozwojem technologii «ściskania czasu", wyraźnie współbrzmi z logiką gospodarki nastawionej na konsumenta: konsument powinien być zadowolony w jednej chwili" - pisał Zygmunt Bauman (2000, s. 97). „Teraz” w jego ujęciu to kwintesencja konsumpcji i kultury konsumpcyjnej, konsumpcyjnego nastawienia do życia. Zmiana, nowość, szybkość, natychmiastowość, ulotność i nietrwałość są wpisane w konsumpcję niejako z istoty rzeczy; charakterystycznym rysem takiego społeczeństwa jest nienasycenie, o którym pisał Daniel Bell (1994), i „syndrom niecierpliwości” w ujęciu Zygmunta Baumana (2003, s. 95; 2004, s. 170). Kompulsywne, obsesyjne zmienianie to typowa dla konsumpcji strategia zużywania i tworzenia 
odpadków, to jednocześnie sztuka zapominania tego, co zużyte, wyparte, zastąpione przez nowe i nowsze. Zespół zjawisk temporalnych związanych z konsumpcją to według badaczy prototyp tego, co dzieje się w innych sferach życia, zmienność, nietrwałość i ulotność odnoszą się do całego życia i kultury, do tożsamości jednostek, stosunków i więzi międzyludzkich, miłości, etyki, twórczości, pracy sztuki, stosunku do przyrody itd. ${ }^{3}$ Wytworem kultury teraźniejszości jest „człowiek synchroniczny” (kolejna koncepcja Stephena Bertmana), żyjący tylko w teraźniejszości, pozbawiony związków z przeszłością i przyszłością, nieuwzględniający ani doświadczeń przeszłości, ani przyszłych konsekwencji dzisiejszych działań, co przekłada się na brak trwalszych więzi z innymi.

Badacze fenomenu dominującej teraźniejszości dostrzegają wiele jej negatywnych konsekwencji w różnych sferach życia i w związku z tym wysuwają propozycje działań naprawczych. Stephen Bertman (1998) proponuje, by poddać kontroli kulturę przyspieszenia, odkryć, że to, co powolne, niekoniecznie jest złe, a to, co szybkie, nie zawsze musi być dobre. „Slow is beautiful” — pisze. Wskazuje też na potrzebę odbudowania związków teraźniejszości z przeszłością i przyszłością ${ }^{4}$. Inni badacze wysuwają podobne hasła: „Robić mniej, posiadać mniej i częściej mówić: nie” (Robinson, Godbey 1999, s. 314). Programy i pomysły naprawcze pojawiają się też $\mathrm{w}$ książce Thomasa H. Eriksena Tyrania chwili (2003). Dostrzega on zgubne konsekwencje pośpiechu i przyspieszenia w wielu aspektach życia człowieka współczesnego: w życiu rodzinnym, pracy polityce, konsumpcji, także w stylu myślenia (Eriksen 2003, s. 7). To, co dzieje się obecnie, interpretuje - podobnie jak inni badacze - jako sferę niezamierzonych konsekwencji rozwoju technologii informacyjnych i komunikacyjnych i pokazuje ich paradoksalne skutki. Dążenie do większej elastyczności w efekcie zmniejsza zatem elastyczność, większe możliwości wyboru ograniczają wybór, a wprowadzenie technik oszczędzających czas ostatecznie prowadzi do zmniejszania się zasobów czasu (Eriksen 2003, s. 14, 202). Opis różnych negatywnych konsekwencji czasu sprowadzonego do chwili (degradacja życia rodzinnego, zjawisko monogamii seryjnej, kult młodości, kryzys przekazywania wiedzy itd.) kończy postulatami w obronie czasu wolno płynącego i wskazaniem potrzeby odpowiednio zorientowanej polityki społecznej. „Powolność potrzebuje ochrony. Potrzebuje wszelkiego rodzaju pomocy państwa, przywilejów społecznych, systemów subsydiów i kwot" (Eriksen 2003, s. 222). Potrzebna jest też na poziomie jednostek „świadoma kontrola nad własnymi zmianami rytmu upływu czasu" (Eriksen 2003, s. 225).

\footnotetext{
3 Procesy te opisuje Zygmunt Bauman, którego niemal cała twórczość jest wielowątkową wypowiedzią na temat czasu w kulturze i społeczeństwie (zob. Tarkowska 2005).

${ }^{4}$ Warto dodać, że choć cała książka Bertmana Hyperculture: The Human Cost of Speed jest krytyką szybkości i tyranii „teraz” z punktu widzenia kosztów ludzkich i społecznych, autor oddaje też sprawiedliwość pozytywnym aspektom i konsekwencjom „siły teraźniejszości” (Bertman 1998, s. 191 i nast.).
} 
Warto tu wspomnieć o innych działaniach i inicjatywach na rzecz czasu wolno płynącego, pojawiających się coraz liczniej, takich jak utworzony w 1999 ro$\mathrm{ku}$ Swiatowy Instytut na Rzecz Spowolnienia (World Institute of Slowness), propagujący rewolucję $w$ tym zakresie, czy jak rozwijający się w ostatnich latach slow movement, obejmujący coraz więcej dziedzin życia (Pańków 2009) ${ }^{5}$. Manuel Castells opisuje Fundację Długiego Teraz (Long Now Foundation), grupująca kalifornijskich naukowców, artystów, biznesmenów, zainteresowanych długoterminową perspektywą czasu, przeciwstawiających się pojęciu czasu błyskawicznego (instant time). Jedną z ich inicjatyw jest zbudowanie Zegara Długiego Teraz, który rejestrowałby czas przez 10 tysięcy lat - wydawałby sygnały dźwiękowe raz do roku, jeden raz na stulecie i jeden raz na tysiąclecie (Castells 2007, s. 464-465).

Można by podać więcej przykładów inicjatyw w obronie czasu wolno płynącego, w obronie długiej perspektywy czasu, w obronie przeszłości i przyszłości, która winna wzbogacić teraźniejszość. Niektórzy badacze dostrzegają już symptomy zmiany zwolnienia tempa i zmęczenia przyspieszeniem. Wydaje się jednak, że rację miał wybitny socjolog czasu, Sebastian de Grazia, który uważał, że podobnie jak długiego okresu, co najmniej dwustu lat, potrzebowała nasza cywilizacja, by nabrać przyspieszenia, tak i proces spowolnienia będzie długotrwały (de Crazia 1962, za: Robinson, Godbey 1999, s. 314). Chyba że w sukurs działaniom i inicjatywom podejmowanym na rzecz czasu wolno płynącego przyjdzie światowy kryzys ekonomiczny, który radykalnie zmieni obecne zasady rządzące życiem społecznym i kulturą i zmusi do głębokiego przewartościowania zmienności i trwania. Jak przypuszcza Zygmunt Bauman, kryzys może wprowadzić rewolucyjne zmiany polegające na zerwaniu z kluczową dla społeczeństwa konsumpcyjnego zasadą „pozbywania się starego, żeby nabyć coś nowego”. „Moim zdaniem - mówi autor Ptynnych czasów - nowością, do której się trzeba będzie przyzwyczaić, będzie odkrycie na nowo wartości trwania” (Bauman 2009). Byłaby to rzeczywiście rewolucyjna, niezwykle głęboka zmiana.

\section{W STRONĘ PERSPEKTYWY LOKALNEJ}

Zarówno rozwój techniki, innowacje technologiczne, nowe media, jak i sfera konsumpcji, rynku i reklamy to zespoły zjawisk o charakterze ogólnocywilizacyjnym, działających w skali globalnej. Ale można dostrzec też działanie czynników lokalnych, wzmacniających czy wspomagających, a niekiedy być może też utrudniających kształtowanie się zjawisk składających się na fenomen rozszerzonej, dominującej teraźniejszości. Na przykład Stephen Bertman, który w swojej koncepcji kultury teraźniejszości i człowieka synchronicznego odwo-

${ }^{5} \mathrm{~W}$ Polsce badania na temat tego ruchu prowadzi Agata Gruszecka, doktorantka Szkoły Nauk Społecznych przy IFiS PAN. 
łał się do realiów społeczeństwa amerykańskiego i dokładnie przeanalizował rolę zarówno nowych technologii komunikacyjnych i informacyjnych, jak i konsumpcyjnego stylu życia, dostrzegł jeszcze jedno źródło amerykańskiej obsesji szybkości, fascynacji nowością i zmiennością. Wiązał je z historią społeczeństwa amerykańskiego, ze specyficznym doświadczeniem historycznym i społecznym Amerykanów, na które składa się między innymi dziedzictwo migracji do Nowego Świata, a następnie doświadczenie i mit pogranicza, przybierający ciągle nowe wcielenia (takie jak mit podboju kosmosu). Mobilność w przestrzeni sprzyjała pozytywnemu wartościowaniu zmiany ruchu, nowości i młodości, a jednocześnie miała wpływ na krótką pamięć historyczną. „Jako Amerykanie - pisał Bertman (1998, s 30) - zawsze byliśmy chronicznymi emigrantami w poszukiwaniu domu; zasiedlając nowe tereny byliśmy wygnańcami z czasu".

Również w wypadku społeczeństwa polskiego i charakterystycznego dla niego czasu społecznego można wyodrębnić działanie czynników różnej natury, o charakterze zarówno globalnym (nowe technologie komunikacyjne i informacyjne, oddziaływanie kultury konsumpcyjnej), jak i bez wątpienia lokalnym - chodzi o wpływ specyficznego dziedzictwa i doświadczenia historycznego i społecznego. W efekcie ukształtowało się to, co od wielu lat określam mianem orientacji prezentystycznej Polaków (Tarkowska 1987, 1992) i co jest odpowiednikiem zarysowanej kultury teraźniejszości. Jak starałam się pokazać w różnych miejscach (Tarkowska 1992, 1999, 2004), obecna postać czasu społecznego Polaków jest swoistą wypadkową czterech grup kumulujących się uwarunkowań i doświadczeń, prowadzących w różny sposób do koncentracji na teraźniejszości i do zredukowanej perspektywy przyszłości. Sprawą odrębną, dotyczącą zresztą nie tylko polskich realiów, jest towarzyszący wskazanym procesom żywy, emocjonalnie zabarwiony stosunek do przeszłości. Owe uwarunkowania to: po pierwsze, dziedzictwo 45 lat tzw. socjalizmu realnego, wpływ specyficznych uwarunkowań systemowych na zachowania, mentalność, styl życia; poczucie zależności i przymusu oraz braku wpływu na rzeczywistość; po drugie, specyficzne dziedzictwo kulturowe, ze szczególnym uwzględnieniem pewnych elementów tradycyjnej kultury chłopskiej, słabości lub nieobecności wartości mieszczańskich, ludowej religijności i tzw. etyki katolickiej; po trzecie, oddziaływanie okresu transformacji, okresu głębokich zmian charakteryzujących się wyjątkową nieciągłością i niestabilnością, przyspieszeniem i nagromadzeniem zmian zachodzących właściwie we wszystkich sferach życia; doświadczenie „permanencji zmiany”; po czwarte, globalne procesy o charakterze zmian cywilizacyjnych, prowadzące do kompresji czasu; wpływ nowych technologii informacyjnych i komunikacyjnych oraz rynku i konsumpcji, zwiększających i wzmacniających rolę teraźniejszości.

Przeprowadzone w końcu lat osiemdziesiątych i na początku dziewięćdziesiątych analizy, których fundamentem była różnego rodzaju empiria, stały się podstawą twierdzenia o dominacji w Polsce orientacji prezentystycznej, skoncentrowanej na „teraz”, ze skróconą, zablokowaną perspektywą przyszłości 
(Tarkowska 1987, 1992). Tego typu orientacje pojawiają się w sytuacjach zależności i przymusu, politycznego, ekonomicznego czy innego; zredukowana perspektywa przyszłości jest pochodną braku wpływu na teraźniejszość. Poza tym do podobnych skutków prowadzą sytuacje ograniczające lub uniemożliwiające antycypację dalszego biegu wydarzeń, czyli okresy gwałtownych zmian, naruszających ciągłość czasu i w ten sposób uniemożliwiających przewidywanie (Nelkin 1970). W powojennej historii Polski widoczne było oddziaływanie obu grup czynników, choć $\mathrm{w}$ różnym nasileniu w poszczególnych okresach. Zależności i przymusy natury politycznej charakteryzowały cały okres realnego socjalizmu, z kolei zmiana i niestabilność to trwałe ramy życia społecznego w tej części Europy, w której dziejach współczesnych widać, jak to kiedyś określił Tadeusz Łepkowski (1989), „coraz więcej zmian, coraz mniej trwania”.

Wielu teoretyków i badaczy systemów komunistycznych wskazywało na niepewność i nieprzewidywalność warunków działania jako charakterystyczny element gospodarki centralnie planowanej. „Źródłem niepewności był autorytarny charakter systemu, stwarzający zarówno możliwości arbitralnych decyzji, jak i nagłych, też arbitralnych zmian tych reguł" (Tarkowski 1994, s. 89). Zniechęcało to do planowania lub wręcz je uniemożliwiało, unieważniając tym samym przyszłość. Pokazuje to wiele ówczesnych badań socjologicznych, między innymi przeprowadzone w 1969 roku międzynarodowe badania porównawcze na temat wyobrażeń roku 2000. W ramach tych badań Polskę zaliczono do grupy krajów o orientacji prezentystycznej, z wyraźną dominacją teraźniejszości i niedostatecznym zainteresowaniem przyszłością: dla ponad połowy Polaków (i to młodych Polaków, gdyż respondentami byli ludzie w wieku 15-40 lat) przyszłość nie była przedmiotem większego zainteresowania (Siciński 1975; Ornauer i in. 1976). Do zbliżonych wniosków skłaniały inne badania, prowadzone w latach sześćdziesiątych i siedemdziesiątych czy osiemdziesiątych, pokazujące wysokie miejsce w hierarchii wartości Polaków wartości określanych jako prywatno-stabilizacyjne. Elementy orientacji prezentystycznej można było znaleźć u przedstawicieli różnych grup i kategorii społecznych: u ludzi starych i młodych, ubogich i dobrze sobie radzących, także w wypowiedziach decydentów różnych szczebli, czyli ludzi, którzy realizowali zaplanowane działania i przynajmniej teoretycznie powinni mieć poczucie wpływu na rzeczywistość (zob. Tarkowska 1992). Myślenie w kategoriach odległych celów występowało w grupach i ruchach alternatywnych, skoncentrowanych na wartościach wymagających długiej perspektywy czasu, takich jak ekologia czy zdrowie (Tarkowska 1991), także wśród opozycji politycznej.

Orientacji skoncentrowanej na teraźniejszości sprzyjały też inne czynniki, w tym specyficzne dziedzictwo kulturowe: tradycyjna kultura chłopska, słabość wartości mieszczańskich, oddziaływanie religii katolickiej. Zarówno działanie tradycyjnej kultury chłopskiej, jak i oddziaływanie systemu komunistycznego przebiegało $\mathrm{w}$ podobnym kierunku, jak to pokazał $\mathrm{w}$ jednym $\mathrm{z}$ tekstów Zygmunt Bauman: 
„Warunki, w jakich stawia się czoło i rozwiązuje życiowe problemy w społeczeństwach komunistycznych, można traktować jako zgeneralizowaną wersję warunków, z jakimi styka się przedindustrialny chłop. Jeśli jako dominującą cechę życia przedindustrialnego chłopa wyróżniliśmy niepewność, pozostaje ona też najdonioślejszą cechą społeczeństwa komunistycznego, następującego po społeczeństwie chłopskim. Tyle tylko, że główne źródło niepewności przemieściło się z natury do społeczeństwa” (Bauman 1979, s. 185).

Mówiąc o dziedzictwie kulturowym, trzeba też wspomnieć o niedostatku i słabości w Polsce kultury mieszczańskiej i mieszczańskiego stylu życia, z takimi typowymi dla niego wartościami jak szacunek wobec czasu („,czas to pieniądz"), oszczędzanie z myślą o przyszłych korzyściach, długoterminowe planowanie. Nieobecność wartości od czasów Maksa Webera wiązanych z etyką protestancką skłania do poszukiwania wpływu katolicyzmu i związanych z nim wartości. Jak twierdzi autor koncepcji „etyki katolickiej”, konstruktu analogicznego do etyki protestanckiej, wartości z nią związane sprzyjają eksponowaniu teraźniejszości, a nie przyszłości (Dealy 1977).

Koncentracji na teraźniejszości sprzyjał także okres transformacji lat dziewięćdziesiątych, odznaczający się głębokimi zmianami w wielu sferach życia, co swego czasu nazwałam permanencją zmiany. Doświadczenie zmienności, nietrwałości, tymczasowości otaczającej rzeczywistości, typowe dla kultury współczesnej w skali globalnej i zasadnicze dla fenomenu rozszerzonej teraźniejszości, w warunkach polskich znalazło dodatkowe wzmocnienie.

Jeśli chodzi o procesy w skali globalnej prowadzące do kultury teraźniejszości, takie jak nowe technologie komunikacyjne i informacyjne czy ekspansja konsumpcji i kultury konsumpcyjnej, to ich oddziaływanie w społeczeństwie polskim jest widoczne, choć niewątpliwie mają mniejszy zasięg i nasilenie niż w społeczeństwach zachodnich czy w społeczeństwie amerykańskim. Coraz liczniejsze prace opisujące oddziaływanie nowych mediów i kultury popularnej wskazują na obecność kultury teraźniejszości także w naszych warunkach.

\section{ZRÓŻNICOWANIA I PODZIAŁY ZWIĄZANE Z CZASEM}

Przedstawiony obraz przemian czasu społecznego, zachodzących zarówno w skali globalnej, w kontekście procesów ogólnocywilizacyjnych, jak i w wymiarze lokalnym, ograniczonym do przypadku polskiego, jest ujęciem uproszczonym, ukazującym tylko jedną stronę złożonych zjawisk. W świecie współczesnym nie wszyscy cierpią na brak czasu, nie wszyscy żyją w pośpiechu, nie dla wszystkich głównym środowiskiem temporalnym jest hiperkultura i rozszerzona teraźniejszość. W zróżnicowanych i podzielonych społeczeństwach nierówności społeczne i ekonomiczne są wzmacniane przez nierówności związane $z$ czasem. Wielu badaczy czasu zwraca uwagę na to, że współczesne społeczeństwa żyją w dwu rytmach, przy czym żyjący szybciej należą do kategorii uprzywilejowanych, a niepracujący i bezrobotni odczuwają zatrzymanie czasu. „Kur- 
czenie się przestrzeni niweluje wymiar czasu. Mieszkańcy pierwszego świata pogrążeni są w ciągłej teraźniejszości, a ich życie jest ciągiem epizodów higienicznie oddzielonych od przeszłości i przyszłości. Ludzie ci są stale zajęci i ciągle brakuje im czasu" - pisał Zygmunt Bauman w Globalizacji (2000, s. 105). Ludzie należący do drugiego świata „są przygnieceni bezużytecznym ciężarem nadmiaru czasu, którego nie mają czym wypełnić. W ich czasie «nic się nigdy nie zdarza» [...]. Mogą oni jedynie zabijać czas, tak jak on ich powoli zabija". Socjologowie czasu, na przykład Helga Nowotny czy Gabriela Paolucci, a także badacze innych specjalności, piszą o nowej stratyfikacji związanej z czasem, wskazują na nowy nie mający jeszcze nazwy konflikt, wyrażający się w podziale na posiadaczy pracy i bezrobotnych, na przepracowanych i niepracujących, na cierpiących na brak czasu i odczuwających jego nadmiar. Podobny może nie tyle konflikt, ile głęboki podział społeczny określiłam terminem „nierównej dystrybucji czasu", odnosząc go do zmieniającego się społeczeństwa polskiego pierwszej połowy lat dziewięćdziesiątych (Tarkowska 1997). W przeciwieństwie do uniformizującego i homogenizującego pod tym względem oddziaływania systemu realnego socjalizmu w wyniku reform rynkowych społeczeństwo wyraźniej zróżnicowało się i spolaryzowało na żyjących w nowym, przyspieszonym tempie, w nieustannym pośpiechu i odczuwających chroniczny deficyt czasu oraz na tych, którzy $z$ różnych powodów (brak pracy, niepełnosprawność, choroba, starość) odczuwają nadmiar niezagospodarowanego czasu.

W okresie PRL ilość czasu wolnego była jednym ze wskaźników stopy życiowej i pozycji społecznej: zasoby czasu do swobodnej dyspozycji były tym większe, im wyższe miejsce się zajmowało w hierarchii społecznej. Wyższemu poziomowi wykształcenia czy wyższym kategoriom dochodów towarzyszyły większe zasoby czasu wolnego (Anasz 1981, s. 180; Wnuk-Lipiński 1981, s. 150). Deficyt czasu był na ogół skorelowany z niskimi kwalifikacjami, niskimi dochodami, a także $z$ trudną sytuacją życiową rodzin wielodzietnych lub rodzin z małymi dziećmi wymagającymi opieki.

Okres transformacji przyniósł w tej dziedzinie zasadnicze zmiany. W wyniku przemian, które istotnie przekształciły czas pracy i czas wolny, zmieniło się też ich miejsce w hierarchii wartości. Wraz z odkryciem czasu jako ekonomicznie wymiernej wartości miejsce czasu wolnego jako wartości cennej i poszukiwanej zajęła praca. Wyżej ulokowanych na drabinie społecznej (ludzie dobrze sytuowani, pracujący na własny rachunek, ludzie z wyższym wykształceniem) charakteryzuje deficyt czasu, w przeciwieństwie do niższych grup dochodowych, które nie tylko nie odczuwają braku czasu, ale raczej cierpią na jego nadmiar (Tarkowska 1997).

\section{SŁOWO KOŃCOWE}

Posługując się kategorią kultury teraźniejszości, eksponującą element „teraz", przyspieszenie i deficyt czasu, trzeba pamiętać o jej ograniczeniach, czyli 
o tym, że są ludzie, zbiorowości czy społeczeństwa, które żyją poza ramami owej kultury. Nie podważa to jednak przydatności tej kategorii jako narzędzia odsłaniającego ważne aspekty kultury współczesnej i życia społeczeństw współczesnych, zarówno w skali globalnej, jak i w wymiarze lokalnym.

\section{BIBLIOGRAFIA}

Adam Barbara, 1995, Timewatch: The Social Analysis of Time, Polity Press, Cambridge.

Anasz Marian, 1981, Wybrane cechy sposobu życia klas $i$ warstw spotecznych, w: Lidia Beskid, Zbigniew Sufin (red.), Warunki życia i potrzeby społeczeństwa polskiego $w$ połowie lat siedemdziesiatych, IFiS PAN-IPPM-L KC PZPR, Warszawa.

Aveni Anthony F., 2001, Imperia czasu. Kalendarze, zegary i kultury, tłum. Paweł Machnikowski, Zysk i S-ka, Poznań.

Bauman Zygmunt, 1979, Comment on Eastern Europe, „Studies in Comparative Communism”, t. 12, nr 2-3.

Bauman Zygmunt, 1998, Śmierć i nieśmiertelność. O wielości strategii życia, tłum. Norbert Leśniewski, Wydawnictwo Naukowe PWN, Warszawa.

Bauman Zygmunt, 2000, Globalizacja. O co z tego dla ludzi wynika, tłum. Ewa Klekot, PIW, Warszawa. Bauman Zygmunt, 2006, „Czas w epoce płynnej nowoczesności”, wykład w SWPS, 16 października.

Bauman Zygmunt, 2009, Koniec orgii. Z Zygmuntem Baumanem rozmawia Tomasz Kwaśniewski, „Duży Format” (dodatek do „Gazety Wyborczej”), 9 lutego.

Bell Daniel, 1994, Kulturowe sprzeczności kapitalizmu, tłum. Stefan Amsterdamski, Wydawnictwo Naukowe PWN, Warszawa.

Bertman Stephen, 1998, Hyperculture: The Human Cost of Speed, Praeger, Westport, Conn.

Castells Manuel, 2007, Społeczeństwo sieci, tłum. Mirosława Marody i in., Wydawnictwo Naukowe PWN, Warszawa.

De Grazia Sebastian, 1962, Of Time, Work, and Leisure, Twentieth Century Found, New York.

Dealy Glen C., 1977, The Public Man: An Interpretation of Latin American and Other Catholic Countries, University of Massachusetts Press, Amherst.

Elias Norbert, 1992, Time: An Essay, Blackwell, Oxford, UK-Cambridge, MA.

Eriksen Thomas H., 2003, Tyrania chwili. Szybko i wolno ptynacy czas $w$ erze informacji, tłum. Grzegorz Sokół, PIW, Warszawa.

Fraser J. T., 1987, Time, The Familiar Stranger, University of Massachusetts Press, Amherst.

Harvey David, 1989, The Condition of Postmodernity: An Enquiry into the Origins of Cultural Change, Blackwell, Oxford, UK-Cambridge, MA.

Heller Agnes, 1995, Where Are We at Home?, „Thesis Eleven”, t. 41, nr 1.

Kern Stephen, 1983, The Culture of Time and Space 1880-1948, Harvard University Press, Cambridge, MA.

Kępiński Antoni, 1983, Rytm życia, Wydawnictwo Literackie, Kraków.

Łepkowski Tadeusz, 1989, Uparte trwanie polskości. Nostalgie. Trwanie. Nadzieje. Wartości, Aneks-Wolne Pismo Most, Londyn-Warszawa.

Macnaghten Phil, Urry John, 2005, Alternatywne przyrody. Nowe myślenie o przyrodzie i społeczeństwie, tłum. Bogdan Baran, Scholar, Warszawa.

Nelkin Dorothy, 1970, Unpredictability and Life Style in a Migrant Labor Camp, „Social Problems”, t. 17, nr 4.

Nowotny Helga, 1994, Time: The Modern and Postmodern Experience, Wiley, Cambridge.

Ornauer Helmut, Wiberg Hakan, Siciński Andrzej, Galtung Johan (red.), 1976, Images of the World in the Year 2000: A Comparative Ten Nations Study, Humanities Press, The Hague-Paris. 
Pańków Lidia, 2009, Leniwa niedziela, „Wysokie Obcasy”, 31 stycznia.

Rifkin Jeremy, 1987, Time Wars: The Primary Conflict in Human History, Henry Holt and Co, New York. Ritzer George, 2001, Magiczny świat konsumpcji, tłum. Ludwik Stawowy, Muza, Warszawa.

Robinson John P., Godbey Geoffrey, 1999, Time for Life: The Surprising Ways Americans Use Their Time, Pennsylvania State University Press, University Park, PA.

Siciński Andrzej, 1975, Młodzi o roku 2000. Opinie, wyobrażenia, postawy, Instytut Wydawniczy CRZZ, Warszawa.

Siwicka Dorota, Bieńczyk Marek, Nawarecki Aleksander (red.), 1996, Szybko i szybciej. Eseje o pośpiechu w kulturze, IBL, Warszawa.

Tarkowska Elżbieta, 1987, Czas w społeczeństwie. Problemy, tradycje, kierunki badań, Ossolineum, Wrocław.

Tarkowska Elżbieta, 1991, „Inność” $i$ „obcość” w perspektywie antropologicznej, w: Jerzy Wertenstein-Żuławski, Mirosław Pęczak (red,), Spontaniczna kultura młodzieżowa. Wybrane zjawiska, Wiedza o Kulturze, Wrocław.

Tarkowska Elżbieta, 1992, Czas w życiu Polaków. Wyniki badań, hipotezy, impresje, Wydawnictwo IFiS PAN, Warszawa.

Tarkowska Elżbieta, 1997, Nierówna dystrybucja czasu — nowy wymiar zróżnicowania społeczeństwa polskiego, w: Henryk Domański, Andrzej Rychard (red.), Elementy nowego ładu, Wydawnictwo IFiS PAN, Warszawa.

Tarkowska Elżbieta, 1999, Polacy wobec przyszłości i przeszłości. Czas społeczny w okresie realnego socjalizmu i w okresie transformacji, w: Ewa Nowicka, Mirosław Chałubiński (red.), Idee a urządzanie świata społecznego. Ksiegga jubileuszowa dla Jerzego Szackiego, Wydawnictwo Naukowe PWN, Warszawa.

Tarkowska Elżbieta, 2004, Changing Social Time in Post-Communist Poland: Local and Global Perspectives, „Essays in Arts and Sciences”, t. 33, nr 2.

Tarkowska Elżbieta, 2005, Zygmunt Bauman o czasie i procesach detemporalizacji, „Kultura i Społeczeństwo", nr 3.

Tarkowski Jacek, 1994, Patroni $i$ klienci, w: Jacek Tarkowski, Socjologia świata polityki, t. 2, Instytut Studiów Politycznych, Warszawa.

Wnuk-Lipiński Edmund, 1981, Budżet czasu — struktura społeczna — polityka społeczna, Ossolineum, Wrocław.

Young Michael, 1988, The Metronomic Society: Natural Rhythms and Human Timetables, Harvard University Press, Cambridge.

Young Michael, Schuller Tom (red.), 1988, The Rhythms of Society, Routledge, London.

Zadrożyńska Anna, 1985, Powtarzać czas początku. O świętowaniu dorocznych świąt w Polsce, Wydawnictwo Spółdzielcze, Warszawa.

\section{NOWIST CULTURE IN THE GLOBAL AND LOCAL VIEW}

\section{Summary}

The author characterizes the spread of nowist culture as a global phenomenon consisting in the compression of the time frame and the emergence of an extended present absorbing the past and the future into the compact time of global society. These results of the impact of technological development, the spread of communication technologies, new media, consumption culture, the market, and advertising have a negative influence on the life of the individual, the permanency of culture, and the transmission of knowledge. The author claims that we must therefore discover anew the value of permanency. 
Local factors have a modifying influence on global processes. In Polish society these are historically conditioned elements of the presentist culture (the communist heritage, the domination of peasant culture, the weakness of urban culture, Catholic culture) and the effects of the systemic transformation. When time was discovered to be an economically measurable value, its place came to be occupied by work. People higher on the economic ladder are characterized by a deficit of time, in contrast to lower income groups, who rather suffer from an excess of time. The author emphasizes that time could become a source of social inequalities in nowist culture.

\section{Key words / słowa kluczowe}

nowist culture / kultura teraźniejszości; extended present / rozszerzona teraźniejszość; global society / społeczeństwo globalne; culture / kultura; Polish society / społeczeństwo polskie 